\title{
PEMANFAATAN TANAMAN TOGA BAGI KESEHATAN KELUARGA DAN MASYARAKAT
}

\author{
Renny Agus Saktiawan ${ }^{1}$, Atmiasri $^{2}$ \\ ${ }^{1}$ Fakultas Keguruan dan Ilmu Pendidikan, Universitas PGRI Adi Buana Surabaya \\ ${ }^{2}$ Fakultas Teknik, Universitas PGRI Adi Buana Surabaya \\ Email : atmi.asri@yahoo.com ${ }^{1}$, renny.Saktiawan09@ gmail.com ${ }^{2}$
}

\begin{abstract}
Medicinal plants are a source of power that has existed since age-old. TOGA used by our ancestors in order to overcome health problems by making various ingredients of medicinal issues. Therefore the use of medicinal plant families or we called TOGA should be developed and circulated in the community, especially for all of households. But many people are still not aware of the utilization of family medicine. People often mistake them for the raw material too produce of traditional medicines and they do not understand yet how to process the material. It can cause side effects that are different for each person if given excessive doses of the drug. Health to our survival is very important, because without health we could not do any activities that can sustain our lifes. The method used observation and documentation. Medicinal plants are all kinds of plants that have their own uses as a medicine. Many parts of the plant can be used, such as the fruit, stems, leaves, and roots or tubers. Processing technology medicinal plants can be done by sorting, alteration, draining, and drying, storage, and so on. While herb processing can be done by grind, boil, and simmer.
\end{abstract}

Keywords: Medicinal plants, TOGA, Benefits, and Processing.

\section{PENDAHULUAN}

Pemerintah telah menetapkan kebijaksanaan dalam upaya pelayanan kesehatan yaitu Primary Health Care (PHC) sebagai suatu strategi untuk mencapai kesehatan semua pada tahun 2000. Salah satu unsur penting dalam PHC antara lain penerapan teknologi tepat guna dan peran serta masyarakat. Untuk lebih meningkatkan penyelenggaraan pembangunan kesehatan yang semakin luas dan kompleks dengan keputusan menteri kesehatan RI No. 99a/Menkes/SK/III/1982 tanggal 2 maret 1982 telah ditetapkan Sistem Kesehatan Nasional yang merupakan penjabaran pola Pembangunan Nasional dan sebagai petunjuk pelaksanaan pembangunan di bidang kesehatan.

Sistem Kesehatan Nasional adalah suatu tatanan yang mencermikan upaya bangsa Indonesia untuk meningkatkan kemampuan mencapai tingkat kesehatan yang optimal, sebagai perwujudan kesejahteraaan masyarakat. Tumbuhan dan hewan serta mineral yang berkhasiat sebagai obat harus dikembangkan dan disebarluaskan agar dapat dimanfaatkan untuk kesehatan masyarakat. Khususnya, untuk tanaman obat menyebarluaskannya dengan cara menanam
TOGA (tanaman obat keluarga). Kegiatan menanam TOGA ini dapat dilakukan di pekarangan rumah masyarakat.

Tanaman Obat Keluarga (TOGA) adalah tanaman hasil budidaya rumahan yang berkhasiat sebagai obat. Tanaman obat yang tergolong rempah-rempah atau bumbu dapur, tananam pagar, tanaman buah, atau tanaman sayur, dapat ditata di pekarangan sebagai toga. Selain sebagai bahan obat bagi anggota keluarga yang sakit, tanaman tersebut dapat dimanfaatkan untuk aneka keperluan sesuai dengan kegunaan lainnya. Tanaman obat keluarga pada hakekatnya sebidang tanah baik di halaman rumah, kebun ataupun ladang yang digunakan untuk membudidayakan tanaman yang berkhasiat sebagai obat dalam rangka memenuhi keperluan keluarga akan obatobatan.

Tanaman obat merupakan salah satu sumber daya yang sudah ada sejak dahulu kala. TOGA dimanfaatkan oleh nenek moyang kita dalam upaya mengatasi masalah kesehatan dengan menjadikan berbagai ramuan bahan tanaman obat. Oleh karena itu pemanfaatan tanaman obat keluarga (TOGA) perlu dikembangkan dan 
disebarluaskan di masyarakat terutama untuk ibuibu rumah tangga. Ibu rumah tangga sangat berperan dalam masalah kesehatan, sehingga apabila anggota keluarga ada yang sakit maka ibu rumah tanggalah yang melakukan pencegahan pertama dalam mengatasi masalah kesehatan. Namun banyak masyarakat yang masih belum paham akan pemanfaatan tanaman obat keluarga. Masyarakat sering salah dalam menentukan bahan baku dalam pembuatan obat tradisional dan tidak mengerti cara untuk mengolah bahan tersebut. Hal ini dapat menyebabkan efek samping yang berbeda bagi tiap orang jika dosis obat diberikan secara berlebihan. Kesehatan bagi kelangsungan hidup kita sangat penting sekali, karena tanpa kesehatan kita tidak dapat melakukan berbagai aktivitas yang dapat mempertahankan hidup.

Budidaya tanaman obat di Toga juga dapat diserang oleh hama dan penyakit. Pengendalian hama dan penyakit secara alami dengan menggunakan pestisida nabati memang tidak seefektif bila menggunakan pestisida sintetis (kimia). Namun dampak di alam dan pada tanaman obat itu sendiri jauh lebih positif apabila diaplikasikan dalam jangka panjang. Menurut Lestari (2008), jika hama dan penyakit menyerang dapat ditanggulangi dengan bahan alami dari tanaman itu sendiri atau tanaman lainnya. Kandungan zat alami yang terkandung pada tanaman tertentu bermanfaat mengusir hama dan penyakit.

\section{METODE PELAKSANAAN}

Metode yang digunakan dalam penulisan artikel ini adalah observasi dan dokumentasi.

a. Observasi

Observasi adalah suatu proses yang kompleks, suatu proses yang tersusun dari berbagai proses biologis dan psikologis. Dua diantara yang terpenting adalah proses pengamatan dan ingatan (Sugiyono, 2013:145). Observasi yang digunakan ialah dengan cara pengumpulan data dengan pengamatan langsung dan pencatatan secara sistematis terhadap obyek.

b. Dokumentasi

Dokumentasi adalah catatan peristiwa yang sudah berlalu. Dokumen bisa berbentuk Tulisan, gambar, karya-karya monumental dari seseorang. Dokumentasi yang dilakukan dengan cara pengambilan dalam bentuk gambar.

\section{HASIL DAN PEMBAHASAN}

\section{a. Hasil}

Pada awal kegiatan KKN-PPM di lingkungan Kedung Wonokerto banyak warga yang belum sadar akan pentingnya manfaat dari taman TOGA. Warga sudah menanam tanaman TOGA di halaman rumahnya, akan tetapi warga masih belum paham dengan kegunaan dan manfaat dari TOGA tersebut. Oleh karena itu,pada kegiatan KKN-PPM ini telah berupaya untuk menyadarkan masyarakat akan pentingnya kegunaan dan manfaat TOGA bagi masyarakat. Upaya yang dilakukan adalah dengan cara menanam tanaman TOGA dan mengadakan penyuluhan kepada warga masyarakat desa Kedung Wonokerto

\section{b. Pembahasan}

Toga adalah singkatan dari tanaman obat keluarga. Taman obat keluarga pada hakekatnya sebidang tanah yang dalam kondisi baik dan subur di halaman rumah, kebun ataupun lading yang digunakan untuk membudidayakan tanaman yang berkhasiat sebagai obat dalam rangka memenuhi keperluan keluarga akan obat-obatan. Kebun tanaman obat atau bahan obat dan selanjutnya dapat disalurkan kepada masyarakat, khususnya obat yang berasal dari tumbuh-tumbuhan.

Seperti yang dinyatakan oleh Permadi (2008), sesuaikanlah jenis tanaman obat yang hendak ditanam dengan penyakit yang hendak diobati serta mudah diolah menjadi simplisia dengan cara sederhana Lebih baik bila memanfaatkan tanaman liar yang lazim ditemukan namun mudah untuk dibudidayakan. Selain untuk bahan obat, sebaiknya tanaman tersebut juga dapat dikonsumsi sebagai pelengkap sayuran, buah-buahan, dan rempah bumbu masak.

Menurut Lestari (2008), beberapa tanaman obat dapat ditanam secara vertikal menggunakan talang-talang alumunium dan besi baja yang dirakit membentuk piramida. Contoh tanaman obat yang dapat ditanam dengan cara ini adalah tanaman yang tidak berkayu seperti daun dewa, sambung nyawa, temutemuan, pegagan, keladi tikus, dan rumput mutiara. Tanaman obat seperti sirih, gondola, cabe jawa, dan alamanda dapat ditanam dengan cara merambatkan tanaman pada dinding hunian, batang pohon atau pagar. Cara lain adalah menggunakan pot gantung pada plafon teras.

Lestari (2008) dan Kardinan \& Agus Ruhnayat (2003) menyatakan bahwa beragam 
bibit tanaman obat dapat diperoleh di dapur seperti umbi bawang, rimpang bumbu dapur. Tanaman obat juga memerlukan perawatan secara rutin agar dapat tumbuh dan berkembang secara optimal. Seperti hal nya penyiraman rutin pada musim hujan satu kali sehari sedangkan musim kemarau dua hari sekali. Lestari (2008) dan Redaksi Agromedia ( 2010) menyatakan bahwa air rebusan telur, air rendaman teh, air bekas mencuci ikan dapat digunakan sebagai siraman karena banyak mengandung kalsium. Air cucian beras dicampur dengan kulit telur yang telah dihancurkan pun dapat digunakan untuk menyiram tanaman karena air ini banyak mengandung hormon giberalin dan auksin yang bagus untuk perkembangan tanaman.

Tanaman obat keluarga pada dasarnya adalah tanaman yang ditanam di halaman rumah, kebun ataupun sebidang tanah yang dimanfaatkan sebagai budidaya tanaman yang berkhasiat sebagai obat dalam rangka memenuhi kebutuhan keluarga akan obat-obatan. Tanaman toga ini dapat dimanfaatkan sebagai bahan ramuan tradisional. Dimana bahan-bahan tersebut diambil dari berbagai bagian dari tanaman tersebut. Sebagai contoh tanaman toga berdasarkan bagian yang digunakan adalah bagian akar atau umbi, daun, buah, dan kulit batangnya.

Faktor lingkungan juga dapat mempengaruhi kualitas tanaman obat. Apabila pasokan cahaya kurang maka tanaman akan kurus, tanaman tumbuh tidak proporsional, dan tidak menghasilkan bunga/buah. Penyiraman yang berlebihan atau media kurang subur akan menyebabkan tanaman tidak segar, menguning, dan mengalami pembusukan pada bagian pucuk. Jadi solusinya, tanaman dipindahkan ke lokasi yang cukup mendapat cahaya dan frekuensi penyiraman dikurangi.

\section{Bagian akar atau umbi}

Bagian akar yang sering kita sebut sebagai rimpang. Dan bagian-bagian tanaman tersebut mempunyai klasifikasi penyembuhan penyakit yang berbeda-beda. Jenis akar yang digunakan sebagai obat contohnya sebagai berikut :

1. Lengkuas merah

Lengkuas yang biasanya digunakan untuk pengobatan adalah jenis lengkuas merah (Alpinia purpurata K Schum). Dalam farmakologi Cina dan pengobatan tradisional lainnya disebutkan, lengkuas merah memiliki sifat antijamur dan antikembung. Efek farmakologi ini umumnya diperoleh dari rimpang yang mengandung basonin, eugenol, galangan dan galangol.

$>$ Penyakit yang dapat diobati :

Reumatik, Sakit Limpa, Gairah seks, Nafsu makan, Bronkhitis; Morbili, Panu.

2. Temulawak

Kandungan Kimia : Daging buah (rimpang) temulawak mempunyai beberapa kandungan senyawa kimia antara lain berupa fellandrean dan turmerol atau yang sering disebut minyak menguap. Kemudian minyak atsiri, kamfer, glukosida, foluymetik karbinol. Dan kurkumin yang terdapat pada rimpang tumbuhan ini bermanfaat sebagai acnevulgaris, disamping sebagai anti inflamasi (anti radang) dan anti hepototoksik (anti keracunan empedu).

$>$ Penyakit yang dapat diobati :

Sakit limpa, sakit ginjal, sakit pinggang, asma, sakit kepala; masuk angin, maag, sakit perut, produksi ASI, nafsu makan; sembelit, sakit cangkrang, cacar air, sariawan, jerawat;

3. Jahe

Jahe (Zingiber officinale), adalah tanaman rimpang yang sangat populer sebagai rempah-rempah dan bahan obat. Rimpangnya berbentuk jemari yang menggembung di ruas-ruas tengah. Rasa dominan pedas disebabkan senyawa keton bernama zingeron.

$>$ Manfaat jahe, berdasar sejumlah penelitian, antara lain:

Merangsang pelepasan hormon adrenalin, memperlebar pembuluh darah, sehingga darah mengalir lebih cepat dan lancar. Tubuh pun menjadi lebih hangat, kerja jantung memompa darah lebih ringan. Akibatnya, tekanan darah menjadi turun.

Jahe mengandung dua enzim pencernaan yang penting. Pertama, protease yang berfungsi memecah protein. Kedua, lipase yang berfungsi memecah lemak. Kedua enzim ini membantu tubuh mencerna dan menyerap makanan. 
Caranya: pukul-pukul jahe segar sepanjang 1 ruas jari, masukkan dalam satu gelas air panas. Beri madu secukupnya, lalu minum. Dapat pula menggunakan sepertiga sendok teh jahe bubuk, atau jika tahan, makan dua kerat jahe mentah.

Membuat lambung menjadi nyaman, dan membantu mengeluarkan angin. Bisa meringankan kram perut saat menstruasi atau kram akibat terlalu banyak mengkonsumsi makanan berlemak.

4. Kencur

Kencur (Kaempferia galanga L.) adalah salah satu jenis empon-empon/tanaman obat yang tergolong dalam suku temutemuan (Zingiberaceae). Rimpang atau rizoma tanaman ini mengandung minyak atsiri dan alkaloid yang dimanfaatkan sebagai stimulan.

\section{$>$ Khasiat Kencur :}

Rimpang kencur bermanfaat sebagai sumber minyak atsiri, penyedap makanan, minuman, juga bahan jamu dan obat. Minyak atsiri dalam kencur berupa sineol, asam metal kanil, dan pendekaan. Minyak atsiri ini biasa diperoleh dengan cara menyuling rimpangnya.

Berdasarkan analisis laboratorium, minyak atsiri dalam rimpang kencur mengandung kurang lebih 23 macam senyawa. Tujuh belas di antaranya mengandung senyawa aromatic, monoterpena, dan seskuiterpena. Senyawa terakhir punya efek mengurangi dan menghilangkan rasa nyeri (daya analgesic). Kencur juga bersifat stimulant, sehingga bias sebagai penambah tenaga. Selain itu juga bersifat karminatif atau meluruhkan angina, jadi menghilangkan kembung di perut.

5. Kunyit

$>$ Manfaat kunyit banyak digunakan sebagai ramuan jamu karena berkhasiat menyejukkan, membersihkan, mengeringkan, menghilangkan gatal, dan menyembuhkan kesemutan. Bermanfaat juga sebagai anti inflamasi, anti oksidan, anti mikroba, pencegah kanker, anti tumor, dan menurunkan kadar lemak darah dan kolesterol, serta sebagai pembersih darah.

\section{Bagian daun}

1. Daun kemangi

Konsumsi lalap kemangi secara rutin dapat mencegah bau mulut, daun kemangi atau sari daun kemangi dapat menyembuhkan penyakit diare, gangguan pada vagina, nyeri payudara, hingga mengatasi batu ginjal dan albuminaria. Daun kemangi berkhasiat ampuh mengatasi keluhan flu, diare, sakit kepala, cacingan, dan sembelit.

> Manfaat untuk mengobati perut kembung, magh, badan lesu, masuk angin, hingga mengatasi kejang. Aroma dari daun kemangi juga dapat digunakan sebagai obat nyamuk.

2. Daun dewa

> Manfaat Efek farmakologis daun dewa adalah antikoagulan (koagulan $=$ zat yang mempermudah dan mempercepat pembekuan darah), mencairkan bekuan darah, stimulasi sirkulasi, menghentikan perdarahan, menghilangkan panas, dan membersihkan racun. Mengatasi kejang pada anak dan beberapa jenis pendarahan. Untuk mengatasi luka terpukul, tak datang haid, pendarahan pada wanita, pembengkakan payudara, batuk, dan muntah darah, tumor, kutil dan kanker

3. Dadap Serep

$>$ Kandungan dan Manfaat :

Daun dadap serep mengandung zat alkaloida yang sifatnya mendinginkan dan antiradang. Kulit kayunya berkhasiat mengencerkan dahak.

$>$ Kegunaan: untuk mengobati demam 
Kulit dan cabang muda dadap serep diremas, sedikit adas dan pulosari diseduh dengan 1 gelas air. Minum ramuan ini 2x sehari. Dan masih banyak kegunaan lain dari dadap serep ini.

\section{Bagian buah}

1. Menngkudu

Senyawa terpenoid adalah senyawa hidrokarbon isometrik yang juga terdapat pada lemak/minyak esensial (essential oils), yaitu sejenis lemak yang sangat penting bagi tubuh. Zatzat terpenoid membantu tubuh dalam proses sintesa organik dan pemulihan sel-sel tubuh. Dalam mengkudu juga terdapat Zat Anti-bakteri Acubin, L. asperuloside, alizarin dan beberapa zat antraquinon.

$>$ Manfaat dari buah mengkudu :

Meningkatkan daya tahan tubuh, menormalkan tekanan darah, melawan tumor dan kanker, menghilangkan rasa sakit, antiperadangan dan anti-alergi, antibakteri, mengatur siklus energi tubuh

2. Belimbing Wuluh

$>$ Kandungan dan manfaat : Penelitian Lembaga Ilmu Pengetahuan Indonesia menyebut, kandungan vitamin $\mathrm{C}$ yang cukup tinggi $(25,8 \mathrm{mg} / 100$ gram) dalam belimbing wulung sangat berkhasiat mengobati sariawan dan gusi berdarah. Untuk mengatasi gusi berdarah cukup dengan menkonsumsi buah segar belimbing atau manisannya secara ritu setiap hari.

$>$ Ada beberapa manfaat lain dari belimbing wuluh yang belum diuji klinis, antara lain:

a. Mengatasi batuk rejan

Ambil sebanyak 10 buah belimbing wuluh dicuci bersih, remas dengan dua sendok air garam. Kemudian saring dan minum dua kali sehari.

b. Untuk obat jerawat.

Ambil buah belimbing wuluh secukupnya lalu ditumbuk halus. Ramuan diremas dengan garam secukupnya dan digunakan untuk menggosok muka yang berjerawat. Obat panu, 10 buah belimbing wuluh dicuci lalu digiling halus. Tambahkan sedikit kapur sirih, diremas sampai rata. Ramuan digunakan untuk menggosok kulit berpanu sebanyak dua kali sehari.

c. Obat darah tinggi

Tiga buah belimbing wuluh dipotong-potong, rebus dengan tiga gelas air sampai tersisa satu gelas. Setelah dingin disaring dan diminum setelah makan pagi. Mengatasi sakit gigi berlubang, lima buah belimbing wuluh dimakan dengan sedikit garam, kunyah di tempat gigi yang berlubang.

\section{Teknologi Pengolahan Tanaman Obat}

1. Penyortiran

Penyortiran harus segera dilakukan setelah bahan selesai dipanen, terutama untuk komoditas temutemuan, seperti: kunyit, temulawak, jahe dan kencur. Rimpang yang baik dengan yang busuk harus segera dipisahkan juga tanah, pasir maupun gulma yang menempel harus segera dibersihkan. Demikian juga untuk tanaman obat yang diambil daunnya maupun herba (Sambiloto, pegagan), setelah dipanen langsung disortir, daun yang busuk, kering maupun gulma lainnya harus segera dipisahkan.

2. Pencucian

Setelah disortir bahan harus segera dicuci sampai bersih jangan dibiarkan tanah berlama-lama menempel pada rimpang karena dapat mempengaruhi mutu bahan. Pencucian harus menggunakan air bersih, seperti : air dari mata air, sumur atau PAM. Cara pencucian dapat dilakukan dengan cara merendam sambil disikat menggunakan sikat yang halus. 
Perendaman tidak boleh terlalu lama karena zat-zat tertentu yang terdapat dalam bahan dapat larut dalam air sehingga mutu bahan menurun. Penyikatan diperbolehkan karena bahan yang berasal dari rimpang pada umumnya terdapat banyak lekukan sehingga perlu dibantu dengan sikat. Tetapi untuk bahan yang berupa daundaunan cukup dicuci dibak pencucian sampai bersih dan jangan sampai direndam berlama-lama.

3. Penirisan dan Pengeringan

Selesai pencucian rimpang, daun atau herbal ditiriskan dirak-rak pengering. Hal ini dilakukan sampai bahan tidak meneteskan air lagi. Untuk komoditas temu-temuan pengeringan rimpang dilakukan selama 4-6 hari dan cukup didalam ruangan saja. Setelah kering rimpang disortir kembali sesuai dengan standar mutu perdagangan atau mungkin dapat diolah lebih lanjut. Khusus untuk rimpang jahe, standar perdagangan dikategorikan sbb: Mutu I : bobot $250 \mathrm{~g} /$ rimpang, kulit tidak terkelupas, tidak mengandung benda asing dan tidak berjamur, Mutu II : bobot 150-249 g/rimpang, kulit tidak terkelupas, tidak mengandung benda asing dan tidak berjamur dan Mutu III: bobot lebih kecil, kulit terkelupas maksimum 10\%, benda asing maksimum 3\% dan kapang maksimum $10 \%$.

4. Penyimpanan

Jika belum diolah bahan dapat dikemas dengan menggunakan jala plastik, kertas maupun karung goni yang terbuat dari bahan yang tidak beracun/tidak bereaksi dengan bahan yang disimpan. Pada kemasan jangan lupa beri label dan cantumkan nama bahan, bagian tanaman yang digunakan, no/kode produksi, nama/alamat penghasil dan berat bersih. Hal-hal yang perlu diperhatikan untuk ruang penyimpanan, yaitu gudang harus bersih, ventilasi udara cukup baik, tidak bocor, suhu gudang maksimal $30^{\circ} \mathrm{C}$, kelembaban udara serendah mungkin $65 \%$ dan gudang bebas dari hewan, serangga maupun tikus dll.

\section{Pengolahan Ramuan}

Beberapa cara mengolah tanaman obat, diantaranya memipis, merebus, dan menyduh.

\section{Memipis}

Biasanya bahan yang digunakan berupa bagian tanaman atau tanaman yang masih segar seperti daun, biji, bunga, dan rimpang. Bahan tersebut dihaluskan dengan ditambahkan sedikit air. Bahan yang sudah halus diperas hingga $1 / 4$ cangkir. Jika kurang dari $1 / 4$ cangkir, air matang ditambahkan pada ampas, lalu diperas lagi.

2. Merebus

Tanaman obat direbus agar zat-zat yang berkhasiat di dalam tanaman larut ke dalam larutan air. Api yang digunakan untuk merebus sebaiknya yang volumenya mudah diatur. Pada awal perebusan digunakan api besar hingga mendidih. Jika telah mendidih, bahan di dalam air dibiarkan selama 5 menit. Selanjutnya, api kompor dikecilkan untuk mencegah air rebusan meluap sampai air rebusan tersisa sesuai kebutuhan. Bahan yang berukuran besar dipotong terlebih dahulu. Air yang digunakan dalam perebusan adalah air yang tidak berwarna, tidak berbau, tidak berasa, dan bening. Air yang kekuningan, berbau, dan mengandung kotoran sebaiknya tidak digunakan.

3. Menyeduh

Bahan baku yang digunakan dapat berupa bahan yang masih segar atau bahan yang sudah dikeringkan. Sebelum diramu, bahan-bahan dipotong kecil-kecil setela hsiap, bahan diseduh dengan air panas. Setelah didiamkan selama 5 menit, bahan hasil seduhan disaring.

\section{Cara Pembuatan TOGA Instan}

Alat dan Bahan:

1. Penggorengan besar/wajan besar

2. Pengaduk kayu/sutel kayu

3. Kompor

4. Toples besar

5. Parut

6. Kain putih tipis 
7. Saringan santan

8. Saringan tepung

9. Jahe (bisa diganti tanaman TOGA yang lain seperti temulawak dan kunyit)

10. Air matang 1 liter

11. Gula pasir $1 \mathrm{~kg}$

Cara Pembuatan:

1. Kupas daan cuci hingga bersih jahe

2. Haluskan jahe ynag sudah bersih menggunakan parut

3. Setelah halus tambahkan air 1 liter air

4. Selanjutnya peras menggunakan kain saring

5. Selanjutkan endapkan sari jahe/kunir/temulawak selama \pm 1 hari

6. Ambil air sari jahe/kunir/temulawak dan jangan sampai pati endapaan terikut

7. Tuang sari jahe satu liter kepenggorengan serta masukkan gula pasir $1 \mathrm{~kg}$

8. Masak di atas kompor sampai mengkristal dengan api kecil

9. Lalu blender dan ayak dengan saringan

10. Instan sudah siap dikemas

Catatan: pembuatan ini dapaat digunakan dengan bahan temulawak, kunir, dan kencur sama dengan proses penjelasan diatas

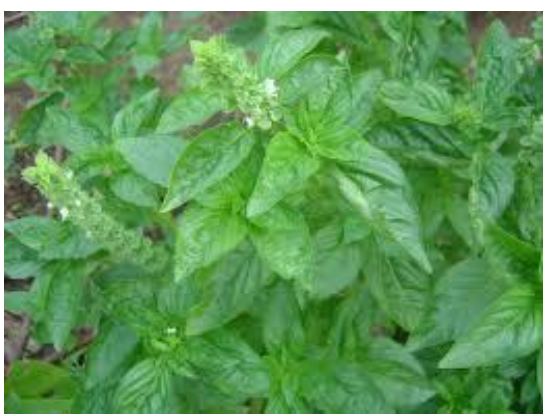

Gambar 1. Daun Kemangi

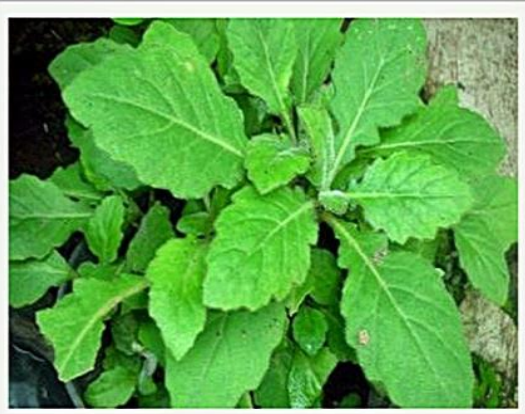

Gambar 2. Daun Dewa

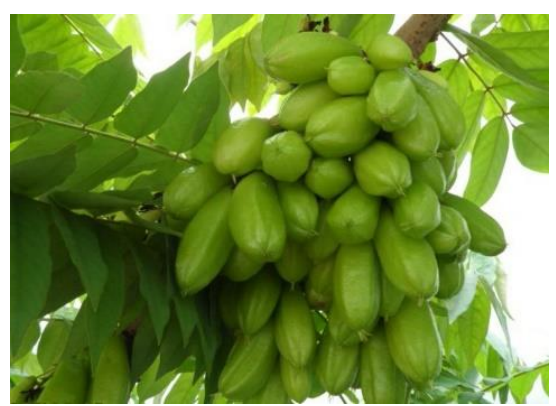

Gambar 3. Belimbing Wuluh

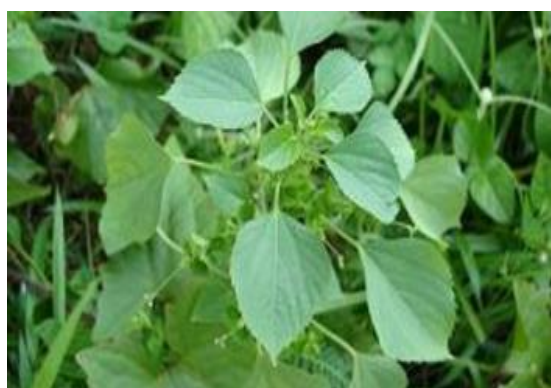

Gambar 4. Daun Dadap Serep

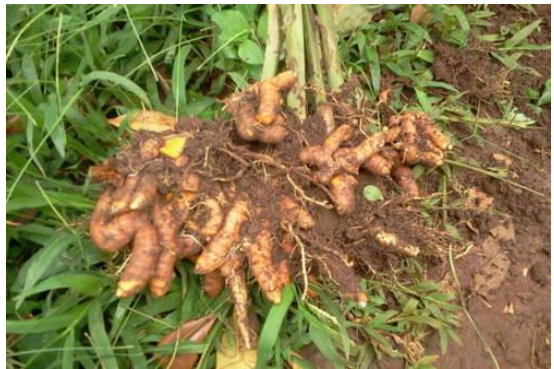

Gambar 5. Kunyit

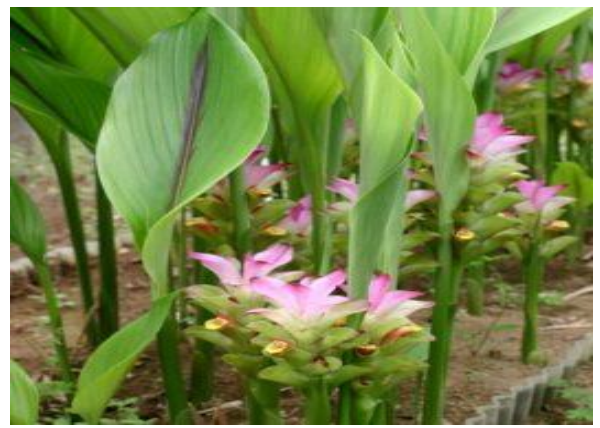

Gambar 6. Temulawak

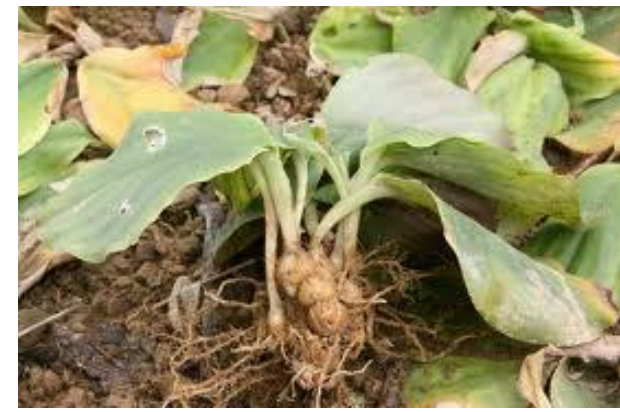

Gambar 7. Kencur 


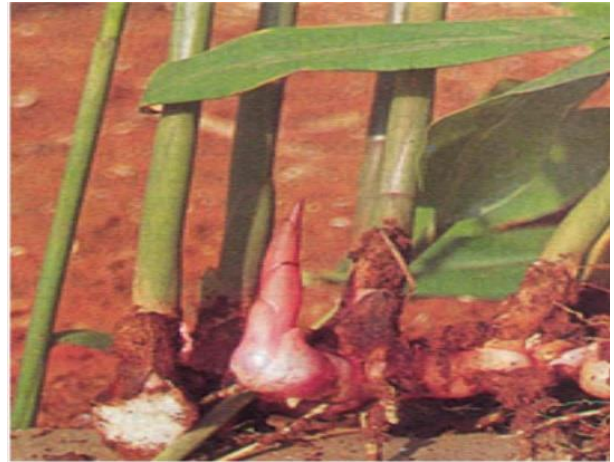

Gambar 8. Lengkuas Merah

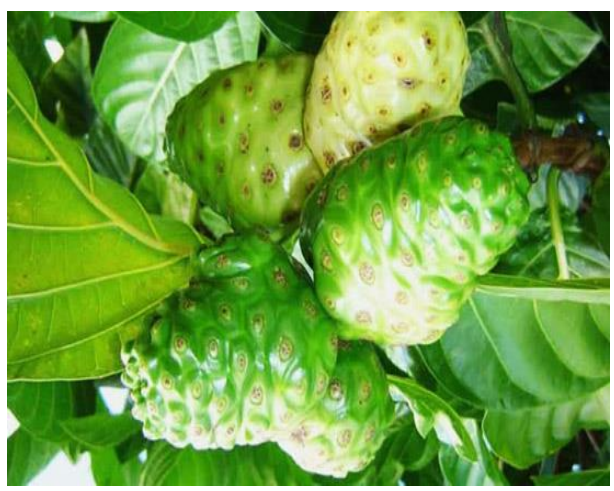

Gambar 9. Mengkudu

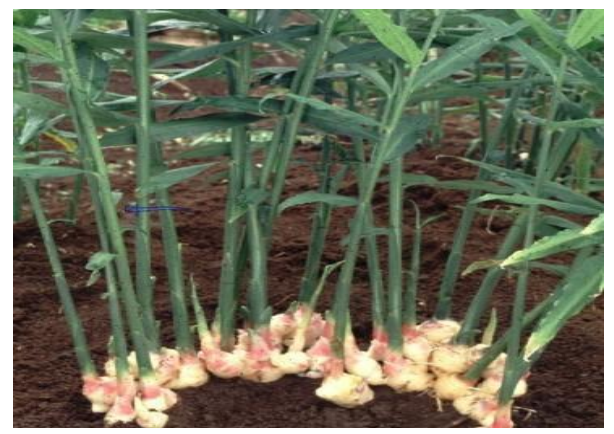

Gambar 10. Jahe

\section{SIMPULAN}

Berdasarkan kegiatan yang telah dilaksanakan. Dapat disimpulkan bahwa program kerja yang dilaksanakan seperti penanaman TOGA dapat bermanfaat bagi keluarga dan masyarakat. Contoh tanaman toga tersebut adalah kemangi, daun dewa, belimbing wuluh, daun dadap serep, kunyit, temulawak, kencur, lengkuas merah, mengkudu, dan jahe. Tanaman TOGA tersebut dapat dioleh menjadi jamu atau obat-obatan tradisional.

\section{REFERENSI}

Depkes Republik Indonesia. 1983. TOGA

(Taman Obat Keluarga). Jakarta.

Sugiyono. 2012. Metode Penelitian Pendidikan Pendekatan Kuantitatif,
Kualitatif dan $R$ \& $D$. Bandung: Alfabeta.

Lestari, Garsinia. 2008. "Taman TOGA”. PT.

Gramedia Jakarta.

Redaksi Agromedia. 2010. "Tips Merawat

Tanaman Hias Populer". PT. Agromedia Pustaka Jakarta. 